\title{
SUMBER PENCEMAR KUALITAS DAN TINGKAT PENCEMARAN AIR DANAU BUYAN DI KECAMATAN SUKASADA KABUPATEN BULELENG BALI
}

\author{
I Made Sumarya*, Ni Ketut Ayu Juliasih, I Putu Sudiartawan \\ Program Studi Biologi Fakultas Teknologi Informasi dan Sains Universitas Hindu Indonesia
}

*Email: sumaryaimade@gmail.com

\section{ABSTRACT \\ SOURCE OF POLLUTANT QUALITY AND LEVEL OF WATER POLLUTION OF BUYAN LAKE IN SUKASADA DISTRICT BULELENG REGECY BALI}

This research objective examined the source of pollutants, water quality and water pollution level of Buyan Lake. The research conducted field observation to identify the source of pollutants, measuring the water quality and water pollution level of Lake Buyan compared to the standard of environmental quality and damage criteria. This research employed the newest standard measurement and equipment in purpose of water and wastewater inspection. Furthermore, this research used STORET method to analys the pollution level. The results discovered that the pollutant's source was the settlement and agricultural activities around Buyan Lake. The average value of physical parameters i.e temperature, dissolved residue (TDS), suspended residue (TSS), turbidity and brightness are $23.02{ }^{\circ} \mathrm{C} ; 127 \mathrm{mg} . \mathrm{L}^{-1}, 4.71 \mathrm{mg} \mathrm{L}{ }^{-1}, 12.52 \mathrm{JTU}$; and $133.6 \mathrm{~cm}$ respectively. The average values of the chemical parameters i.e. $\mathrm{pH}, \mathrm{DO}, \mathrm{BOD}_{5}, \mathrm{COD}, \mathrm{NO}_{3}, \mathrm{NO}_{2}$, Ammonia and Phosphate are 7.48, $5.95 \mathrm{mg} . \mathrm{L}^{-1} *, 25.46 \mathrm{mg} . \mathrm{L}^{-1} *, 42.99 \mathrm{mg} . \mathrm{L}^{-1} *, 1.25 \mathrm{mg} . \mathrm{L}^{-1}, 0.054 \mathrm{mg} . \mathrm{L}^{-1}$, $0.158 \mathrm{mg} . \mathrm{L}^{-1}$, and $0.149 \mathrm{mg} . \mathrm{L}^{-1}$ respectively. The average values of bacteriological parameters i.e Fecal Coliform and Total Coliform are $32.8 \mathrm{MPN} / 100 \mathrm{ml}$ and $392 \mathrm{MPN} / 100$ $\mathrm{ml}$. The comparation results showed that DO, BOD5, COD, $\mathrm{NO}_{2}$, ammonia, phosphate, fecal coliform and total coliform exceed the Class I Standard of Water Quality. STRORET analysis confirmed a high level of pollution i.e. -40 . The overall results show that Buyan Lake water is in the heavily polluted category due to domestic and agricultural activities.

Keywords: Buyan Lake; Pollutant Sources; Pollution Level and Water Quality.

\section{PENDAHULUAN}

Danau merupakan ekosistem perairan darat yang sangat penting bagi kehidupan manusia. Pemanfaatan danau dari berbagai sektor dan aktivitas kehidupan masyarakat di kawasan sekitar danau menyebabkan terjadinya tekanan lingkungan terhadap perairan danau. Akibat adanya tekanan lingkungan menyebabkan fungsi dan manfaat danau akhir-akhir ini terasa terus menurun (Nugroho, Tanjung, \& Hendrarto, 2014). Tekanan lingkungan yang teradi berupa kerusakan lingkungan perairan dan pencemaran danau akibat dari pengelolaan dan pemanfaatannya kurang terkoordinasi diantara sektor-sektor yang terlibat.

Berbagai aktivitas masyarakat seperti permukiman, pertanian kering dan basah, aktivitas budidaya di luar maupun di dalam danau, merupakan sumber pencemar bagi danau. Hal ini penting dan perlu diperhatikan oleh semua pihak agar tidak menjadi 
permasalahan nantinya. Ada beberapa jenis bahan pencemar dapat mencemari air danau diantaranya sedimen, limbah anorganik, limbah organik, residu pestisida dan lain-lain (Marganof, 2007). Keberadaan bahan pencemar tersebut menyebabkan menurunnya manfaat serta fungsi danau.

Danau Buyan adalah salah satu reservoar air alam yang ada di Bali, menjadi sumber mata air bagi kehidupan masyarakat Bali. Air danau Buyan dimanfaatkan untuk berbagai kepentingan seperti pertanian, peternakan, dan kegiatan sehari-hari oleh masyarakat di daerah sekitar danau. Aktivitas masyarakat di daerah tersebut, menyebabkan terjadinya tekanan lingkungan terhadap zona bagian danau yang dekat dengan aktivitas tersebut sebagai akibat dari limbah yang dihasilkan oleh aktivitas masyarakat dikawasan sekitar zona bagian danau tersebut. Tekanan lingkungan tersebut antara lain penggunaan pupuk dan pestisida yang berlebihan pada aktivitas pertanian, limbah domestik dari aktivitas kehidupan masyarakat sehari-hari, erosi dan tanah longsor di kawasan hutan disekitar danau (Sudji, 2015).

Danau Buyan sedang mengalami tekanan lingkungan hal ini diindikasikan oleh indeks keanekaragaman fitoplankton di Danau Buyan yang tergolong rendah yakni 1,09 (Nopiantari, Arthana, \& Astarini, 2017), karena terjadi penambahan unsur hara secara terus-menerus yang menyebabkan terjadinya perubahan laju pertumbuhan organisme perairan sehingga Danau Buyan tergolong kedalam danau mesotrofik (Endarini, 2004). Hasil penelitian Purnomo (2016), mengungkap bahwa alih fungsi lahan untuk kepentingan perumahan dan pertanian, serta limbah yang dihasilkan, telah mengakibatkan degradasi lingkungan yang cukup tinggi di sekitar Danau Buyan (Purnama, 2016). Di samping itu Danau Buyan juga mengalami degradasi berupa pendangkalan/eutrofikasi, pencemaran bahan kimia berbahaya/logam berat dari aktivitas agroindustri, penurunan tinggi muka air dan berkurangnya komunitas ikan tangkap (Putra Manuaba, 2007).

Hasil penelitian Badan Lingkungan Hidup Provinsi Bali pada tahun 2017 dan tahun 2018, menyatakan bahwa status indeks pencemaran Danau Buyan secara berturutturut 2,34 (cemar ringan) dan 9,45 (cemar sedang). Nilai indeks pencemaran ini mengalami peningkatan diakibatkan oleh parameter COD dan BOD yang tinggi. Tingginya konsentrasi COD dan BOD mengindikasikan limbah cair domestik maupun limbah pertanian memiliki konsentrasi bahan organik yang tinggi.

Dengan adanya berbagai aktivitas masyarakat di kawasan sekitar Danau Buyan maka diperkirakan terjadi tekanan lingkungan terhadap zone-zone daerah danau yang dekat dengan pusat-pusat aktivitas masyarakat dikawasan sekitaran danau. Oleh karena itu maka penelitian tentang sumber pencemar, kualitas dan tingkat pencemaran air Danau Buyan menjadi perlu untuk dilakukan.

\section{METODOLOGI}

Penelitian dilakukan dengan metode observasi lapangan yaitu dengan mengidentifikasi sumber-sumber pencemaran, mengambil sampel air danau, mengukur kualitas dan tingkat pencemaran air Danau Buyan. Identifikasi sumber pencemaran perairan danau dilakukan dengan mendata aktivitas masyarakkat dikawasan sekitar danau yang berpotensi menghasilkan zat pencemar, wawancara, pengamatan langsung serta data sekunder. Berbagai sumber pencemar yang menyebabkan air danau tercemar disajikan dalam Tabel 1. 
Tabel 1. Sumber Pencemar, Parameter dan Jenis Data

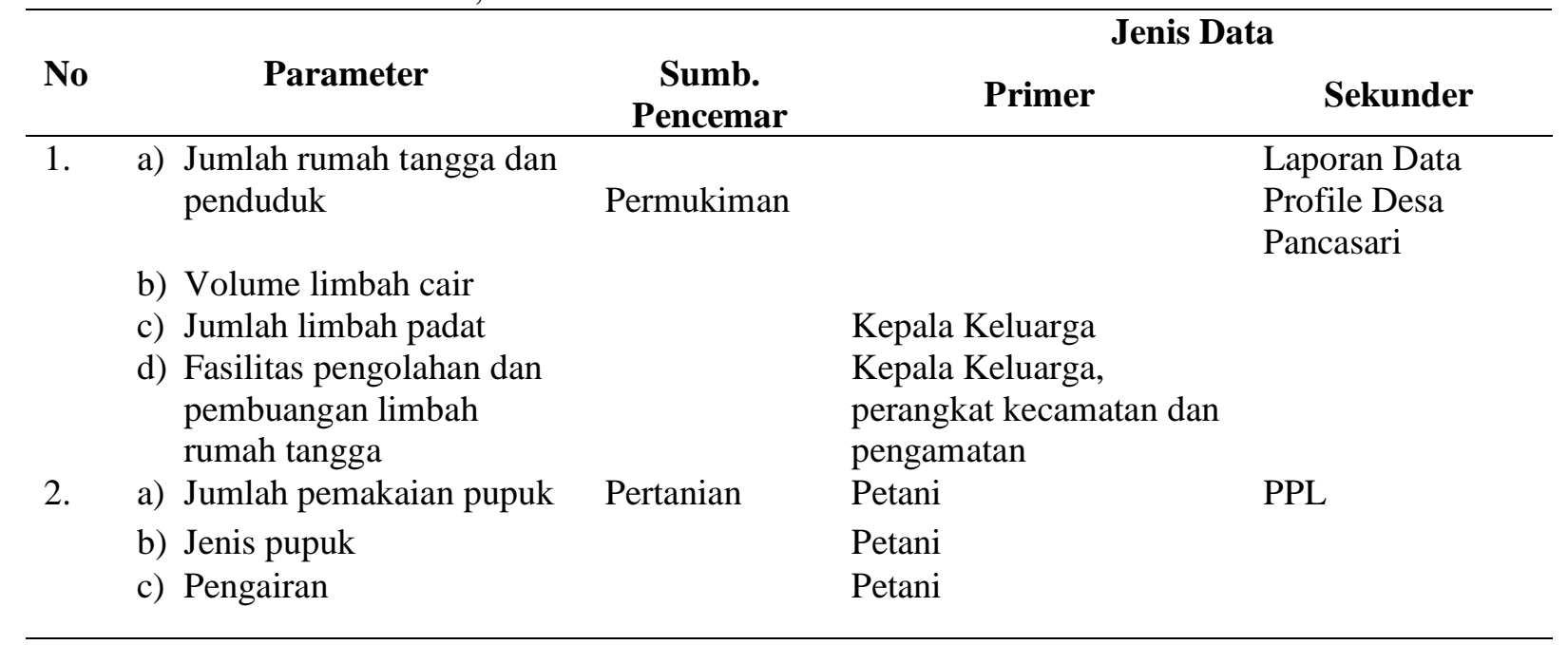

Pengambilan sampel air danau ditujukan pada zone-zone didaerah danau yang dekat dengan pusat-pusat aktivitas masyarakat sebagai sumber pencemar perairan danau serta diambil juga pada lokasi di dekat hutan yang tidak ada aktivitas masyarakatnya dan di lokasi di tengahtengah danau sebagai pembanding. Masingmasing zona daerah danau yang diambil sampel airnya dinyatakan sebagai stasiun pengamatan yang masing-masing jaraknya dari pinggir menuju ke arah tengah danau50 meter. Adapun stasiun-stasiun pengamatan dari pengambilan sampel air danau adalah sebagai berikut:

a. Stasiun I:

Berlokasi di bagian Utara dan Barat danau, berdekatan dengan kawasan hutan. b. Stasiun II

: Berlokasi di tengahtengah danau.

c. Stasiun III : Berlokasi di bagian Selatan danau, berdekatan dengan pemukiman.

d. Stasiun IV : Berlokasi di bagian Timur danau, berdekatan dengan kawasan pertanian di Dusun Dasong.

e. Stasiun V : Berlokasi di bagian Timur danau, berdekatan dengan kawasan pertanian di Dusun Buyan.

Stasiun-stasiun pengamatan tempat mengambil sampel air Danau Buyan dapat dilihat pada Gambar 1. 


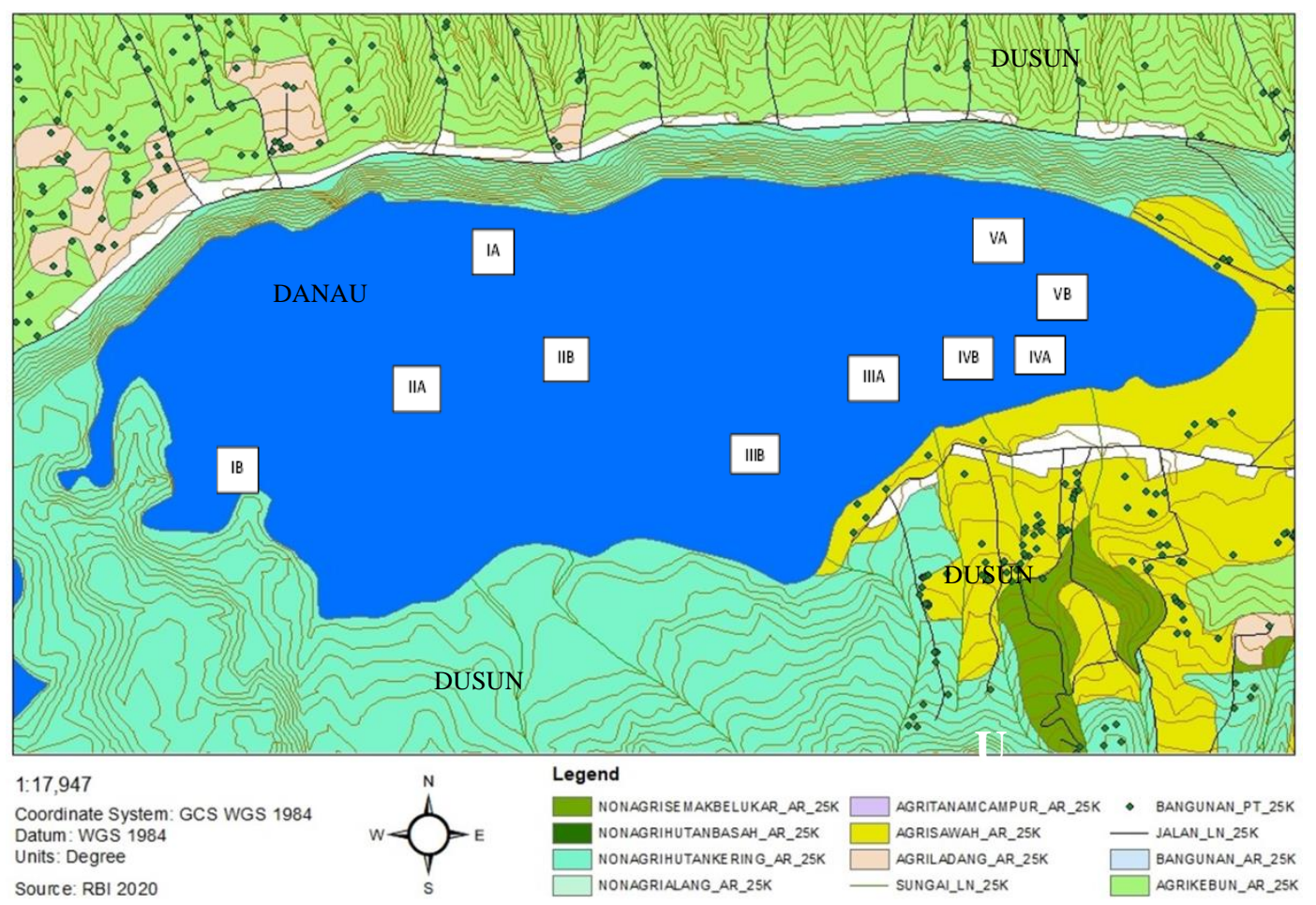

Gambar 1.

Peta Lokasi Tempat Mengambil Sampel Air Danau Buyan

Pengukuran kualitas dan tingkat pencemaran air danau dilakukan dengan menganalisis parameter kimia, fisika dan mikrobiologi dari sampel air danau lalu dikomparasikan dengan arameter baku mutu air (bma) kelas I Pergub Bali No. 16 Tahun 2016 tentang Baku Mutu Lingkungan Hidup dan Kriteria Baku Kerusakan Lingkungan Hidup (Provinsi Bali, 2016). Metode pengukuran parameter kimia, fisika dan mikrobiologi dan alat yang dipergunakan, sesuai dengan metode standar uji air dan air limbah (APHA, 1998), disajikan pada Tabel 2.

Tabel 2. Parameter, Alat, dan Metode Analisis

\begin{tabular}{|c|c|c|c|c|}
\hline No & Parameter & Satuan & Alat & Metode Analisis \\
\hline I. & Kimia & & & \\
\hline 1. & BOD5 & miligram/liter & Peralatan titrasi & Titrimetrik \\
\hline 1 & COD & miligram/liter & Spektrofotometer, titrasi & Spektrofotometrik \\
\hline 2. & DO & miligram/liter & DO-meter & Titrimetri winkler \\
\hline 3. & $\mathrm{Ph}$ & - & $\mathrm{pH}$-meter & Potensiometri \\
\hline 4. & $\mathrm{~N}-\mathrm{NO} 2$ & miligram/liter & Spectrophotometer & Spektrofotometrik \\
\hline 5. & N-NO3 & miligram/liter & Spectrophotometer & Spektrofotometrik \\
\hline 6. & Phospat & miligram/liter & Spectrophotometer & Spektrofotometrik \\
\hline 7. & Ammonia & miligram/liter & Spectrophotometer & Spektrofotometrik \\
\hline II. & Fisika & & & \\
\hline 1. & Kecerahan & $\mathrm{cm}$ & Secchi Disc & Visual \\
\hline 2. & Kekeruhan & JTU & Turbiditimeter & Turbidimetri \\
\hline 3. & TDS & miligram/liter & Timbangan analitik & Gravimetri \\
\hline 4. & TSS & miligram/liter & Timbangan analitik & Gravimetri \\
\hline 5. & Suhu & ${ }^{0} \mathrm{C}$ & Termometer & Pemuaian \\
\hline III. & Mikrobiologi & & & \\
\hline 1. & Total coliform & MPN/100 mL & Tabel MPN, filter & Metode MPN \\
\hline 2. & Fecal coliform & MPN/100 mL & Tabel MPN, filter & Metode MPN \\
\hline
\end{tabular}


Penentuan tingkat pencemaran air danau dianalisis dengan metode STORET dan langkah perhitungannya seperti berikut:

1. Data parameter air danau dibandingkan baku mutu air kelas I Pergub Bali No.16/2016.

2. Data hasil pengukuran yang sesuai dengan standar diberi nilai 0 .

3. Data hasil pengukuran yang tidak sesuai dengan standar dinilai maksimum, minimum dan rata-rata. (lihat Tabel 3).

4. Semua nilai negatif dari seluruh parameter dijumlahkan kemudian total nilainyanya dibandingkan dengan kondisi mutu/tingkat cemar air menggunakan skor dari US-EPA (lihat Tabel 4).

Tabel 3. Nilai Status Mutu Air

\begin{tabular}{ccccc}
\hline Jumlah & Nilai & \multicolumn{3}{c}{ Parameter } \\
\cline { 3 - 5 } Contoh & & Fisika & Kimia & Biologi \\
\hline \multirow{3}{*}{$<\mathbf{1 0}$} & Maksimum & -1 & -2 & -3 \\
& Minimum & -1 & -2 & -3 \\
& Rata-rata & -3 & -6 & -9 \\
$>\mathbf{1 0}$ & Maksimum & -2 & -4 & -6 \\
& Minimum & -2 & -4 & -6 \\
& Rata-rata & -6 & -12 & -18 \\
\hline
\end{tabular}

(Canter,1977) dalam Kepmen LH No. 115, 2003

Tabel 4. Kelas Air berdasarkan US-EPA

\begin{tabular}{ccccc}
\hline No & Kelas & Kondisi & Skor & Keterangan \\
\hline 1 & A & Baik Sekali & 0 & Memenuhi Baku Mutu \\
2 & B & Baik & $-1 \mathrm{~s} / \mathrm{d}-10$ & Cemar Ringan \\
3 & C & Sedang & $-11 \mathrm{~s} / \mathrm{d}-30$ & Cemar Sedang \\
4 & D & Buruk & $\geq-31$ & Cemar Berat \\
\hline
\end{tabular}

(Canter,1977) dalam Kepmen LH No. 115, 2003

\section{HASIL DAN PEMBAHASAN}

\subsection{Hasil Penelitian}

\subsubsection{Identifikasi Sumber Pencemaran}

Sumber pencemar perairan Danau Buyan berasal dari aktivitas masyarakat di kawasaan sekitar danau. Berdasarkan hasil wawancara dengan aparat desa, Kepala Dusun Buyan dan Kepala Dusun Dasong, serta masyarakat setempat, mereka menyatakan sebagian besar mata pencaharian masyarakat adalah petani. Berdasarkan Data Profil Desa Pancasari Tahun 2018, tercatat jenis mata pencaharian masyarakat sebagai petani sebesar $33,13 \%$, buruh tani sebesar $28,76 \%$, sisanya sebesar
38,11 sebagai PNS, wiraswasta, nelayan, buruh dan lain-lain.

Berdasarkan hasil survei di lokasi penelitian dan wawancara dengan aparat Desa Pancasari, yaitu Kepala Dusun Dasong dan Kepala Dusun Buyan, mereka menyatakan pemanfaatan danau oleh masyarakat sekitar adalah untuk irigasi, pertanian, dan sebagian dimanfaatkan oleh penduduk untuk sumber air minum, perikanan dan kegiatan objek wisata. Lebih lanjut dikatakan bahwa untuk saat ini kegiatan perikanan di Danau Buyan sudah tidak memakai keramba jarring apung, karena ada himbauan dari pemerintah untuk tidak menggunakan keramba jaring apung. Para nelayan saat ini mencari ikan hanya dengan meletakkan jaring di perairan danau dengan tujuan ikan terperangkap di jaring, 
tanpa memelihara dan memberikan pakan. Selanjutnya untuk kegiatan pariwisata biasanya dalam bentuk menyediakan tempat di pinggir danau untuk camping yang dikelola oleh KSDA, namun semenjak adanya pandemi Covid-19, objek wisata sudah ditutup atas intruksi pemerintah sejak bulan Maret 2019 sampai batas waktu yang belum ditentukan. Pemanfaatan Danau Buyan dari beberapa sektor serta kegiatan masyarakat di sekitar danau, akan dapat memberikan limbah dari aktivitas tersebut pada perairan danau, melalui aliran air hujan atau aliran air permukaan (run off), hal ini akan berdampak terhadap kualitas air Danau Buyan.

Sumber pencemaran perairan Danau Buyan dapat dikategorikan menjadi dua yaitu dari aktivitas permukiman dan dari aktivitas pertanian di kawasan daerah sekitar danau. Sumber pencemaran dari kegiatan permukiman. Kawasan permukiman di sekitar Danau Buyan ada dua dusun yakni Dusun Dasong dan Buyan. Sumber pencemaran dari kedua dusun permukiman tersebut pada umumnya adalah bersumber dari kegiatan rumah tangga. Dari pengamatan di lapangan dan Berdasarkan hasil survei, ditemukan bahwa masyarakat yang tinggal di permukiman tersebut pada umumnya belum memiliki sistem pengolahan limbah. Limbah hasil kegiatan sehari-hari dari rumah tangga berupa sisasisa makanan, pembersihan lantai, mencuci, mandi, penggunaan toilet (tinja dan air seni) serta jenis lainnya. Sistem pembuangan limbah cair domestik ditampung dalam tangki pembusukan (septic tank), selanjutnya dialirkan ke bidang resapan. Limbah cair domestik yang tidak masuk ke tangki pembusukan dialirkan melalui saluran pembuangan, namun ada juga yang disalurkan langsung ke dalam bak peresapan karena kondisi lahan hunian mereka ada di bawah jalan. Saluran pembuangan yang terdapat di lokasi penelitian ada yang bersifat sementara, sehingga memungkinkan limbah cair merembes dan bercampur dengan air tanah. Saluran pembuangan dari rumah penduduk akan mengalir ke gorong-gorong pembuangan desa yang akan bermuara ke danau. Kondisi seperti ini akan semakin deras pada musim hujan bersama aliran air hujan. Hal ini tentu akan berpotensi mencemari perairan danau. Sedangkan untuk limbah padat berupa sampah domestik diangkut oleh petugas kebersihan desa (jalur jalan utama), namun ada juga sebagian masyarakat yang masih membakar ataupun menimbunnya (terutama sampah kebun) yang umumnya berada di sisi lingkungan tempat tinggal mereka.

Besaran angka timbulan sampah menurut SNI 19-3983-1995, dapat dihitung dengan cara asumsi jumlah sampah yang timbulkan oleh kota kecil/sedang yakni 1,5 2 liter untuk 1orang dalam 1 hari (Badan Standardisasi Nasional, 1995). Mengacu pada standar SNI tersebut maka dapat diasumsikan limbah yang dihasilkan di kawasan permukiman di lokasi penelitian. Berdasarkan hasil wawancara dengan aparat desa, dikatakan jumlah penduduk di Dusun Buyan sebanyak 1.015 orang, sedangkan di Dusun Dasong sebanyak 1.121 orang. Dengan demikian dapat disumsikan jumlah limbah yang dihasilkan dari aktivitas domestik dapat dilihat pada Tabel 5.

Tabel 5. Volume Limbah dari Aktivitas Permukiman

\begin{tabular}{ccccc}
\hline No & Lokasi & Luas (Ha) & $\begin{array}{c}\text { Jumlah } \\
\text { penduduk }\end{array}$ & Estimasi Volume Limbah (lt/hari) \\
\hline 1 & Dusun Buyan & 256 & 1015 & 2030 \\
2 & Dusus Dasong & 256 & 1121 & 2242 \\
& Total & 512 & 2136 & 4272 \\
\hline
\end{tabular}

Sumber: (Badan Standardisasi Nasional, 1995) 
Estimasi volume limbah yang dihasilkan dari aktivitas permukiman di lokasi penelitian diperkirakan sebesar 4272 1t/hari (Tabel 5). Limbah-limbah tersebut dapat masuk ke lingkungan melalui peresapan ke dalam tanah. Limbah-limbah tersebut berpotensi mencemari Danau Buyan, karena limbah tersebut dapat mengalir menuju danau melalui limpasan air permukaan (run off).

Sumber Pencemaran dari Kegiatan Pertanian. Berdasarkan hasil survei dan wawancara dengan penyuluh petani lapangan, dikatakan luas lahan pertanian di sekitar kawasan Danau Buyan adalah sekitar 25 Ha dengan jumlah petani yang tercatat sebanyak 33 orang. Lebih lanjut dikatakan sistem pertanian di sekitar kawasan Danau Buyan adalah sistem pertanian lahan kering. Jenis tanaman yang dibudidayakan adalah jenis tanaman hortikultur seperti selada, wortel, kubis, cabai, tomat, kentang, dan stroberi.

Berdasarkan hasil wawancara diketahui bahwa kegiatan pertanian dilakukan antara lain: penanaman dilakukan 2-3 kali setahun, pengolahan tanah juga dilakukan 2-3 kali sebelum penanaman, penyiraman menggunakan air hujan, air sumur dan air danau tanpa sistem irigasi. Pemupukan menggunakan pupuk anorganik seperti urea, ZA, NPK, KCI dan SP-36 serta pupuk kandang (organik) yang berasal dari tinja sapi. Dosis pupuk yang diterapkan sesuai dengan anjuran penyuluh pertanian lapangan (PPL) dan juga berdasarkan pengalaman para petani yang dianggap memberikan hasil paling optimal. Disamping itu pada saat menjelang panen, dilakukan penyemprotan dengan pestisida untuk menjaga tanaman dari serangan hama dan serangga. Pemakaian dosis pupuk yang berlebihan serta pemakaian pestisida, berpotensi menimbulkan pencemaran lingkungan yang berdampak juga terhadap pencemaran perairan danau. Kegiatan pertanian di daerah sekitar danau baik langsung ataupun tidak dapat mencemari air danau, karena residu pestisida dan pupuk serta limbah organik pertanian akan mengalir ke dalam air danau.

\subsubsection{Kualitas air Danau Buyan}

Sesuai dengan acuan standar air baku Kelas I Pergub Bali No. 16 Tahun 2016, kualitas air Danau Buyan disajikan pada Tabel 6.

Tabel 6. Rerata Hasil Pengukuran Kualitas Air Danau Buyan

\begin{tabular}{|c|c|c|c|c|c|c|c|c|}
\hline No & Parameter (satuan) & $\begin{array}{l}\text { Stasiun } \\
\text { I }\end{array}$ & $\begin{array}{l}\text { Stasiun } \\
\text { II }\end{array}$ & $\begin{array}{c}\text { Stasiun } \\
\text { III }\end{array}$ & $\begin{array}{c}\text { Stasiun } \\
\text { IV }\end{array}$ & $\begin{array}{c}\text { Stasiun } \\
\text { V }\end{array}$ & Rerata & $\begin{array}{l}\text { Baku } \\
\text { Mutu }\end{array}$ \\
\hline \multicolumn{9}{|c|}{ Fisik } \\
\hline 1. & Temperatur $\left({ }^{\circ} \mathrm{C}\right)$ & 23,3 & 23,2 & 23,3 & 22,8 & 22,5 & 23,02 & Deviasi 3 \\
\hline 2. & $\operatorname{TDS}\left(\mathrm{mg} \cdot \mathrm{L}^{-1}\right)$ & 120 & 120 & 130 & 130 & 135 & 127 & 1000 \\
\hline 3. & TSS (mg.L $\left.{ }^{-1}\right)$ & 1,24 & 1,34 & 2,44 & 3,94 & 14,60 & 4,71 & 50 \\
\hline 4. & Kekeruhan (JTU) & 5,03 & 5,25 & 7,34 & 9,28 & $35,69 *$ & 12,52 & - \\
\hline 5. & Kecerahan (cm) & 183 & 193 & 111 & 88 & 93 & 133,6 & - \\
\hline \multicolumn{9}{|c|}{ Kimia } \\
\hline 6 & $\mathrm{pH}$ & 7,5 & 7,6 & 7,2 & 7,6 & 7,5 & 7,48 & $6-9$ \\
\hline 7 . & $\mathrm{DO}\left(\mathrm{mg} \cdot \mathrm{L}^{-1}\right)$ & 6,22 & 6,20 & 6,13 & 6,03 & $5,15^{*}$ & $5,95 *$ & 6 \\
\hline 8. & $\mathrm{BOD}_{5}\left(\mathrm{mg} \cdot \mathrm{L}^{-1}\right)$ & $15,61 *$ & $17,07 *$ & $22,27 *$ & $27,51 *$ & $44,82 *$ & $25,46^{*}$ & 2 \\
\hline 9. & $\operatorname{COD}\left(m g . L^{-1}\right)$ & $27,74^{*}$ & $29,95^{*}$ & $38,41 *$ & $47,79 *$ & $71,07^{*}$ & $42,99 *$ & 10 \\
\hline 10. & $\mathrm{NO}_{3}\left(\mathrm{mg} \cdot \mathrm{L}^{-1}\right)$ & 0,62 & 0,70 & 0,90 & 1,29 & 2,74 & 1,25 & 10 \\
\hline 11. & $\mathrm{NO}_{2}\left(\mathrm{mg} \cdot \mathrm{L}^{-1}\right)$ & 0,03 & 0,024 & $0,077 *$ & $0,088 *$ & 0,051 & 0,054 & 0,06 \\
\hline 12. & Ammonia (mg.L $\left.\mathrm{L}^{-1}\right)$ & 0,037 & 0,038 & 0,048 & 0,045 & $0,62 *$ & 0,158 & 0,5 \\
\hline 13. & Phosphat (mg.L $\left.{ }^{-1}\right)$ & 0,114 & 0,10 & 0,113 & 0,165 & $0,255^{*}$ & 0,149 & 0,2 \\
\hline \multicolumn{9}{|c|}{ BAKTERIOLOGI } \\
\hline 14. & $\begin{array}{l}\text { Fecal coliform } \\
\text { (MPN/100 mL) }\end{array}$ & 0 & 0 & $102 *$ & 26 & 36 & 32,8 & 100 \\
\hline 15. & $\begin{array}{l}\text { Total coliform } \\
\text { (MPN/100 mL) }\end{array}$ & 26 & 34 & $1260 *$ & 325 & 315 & 392 & 1000 \\
\hline
\end{tabular}

Keterangan: *) tidak memenuhi baku mutu 
Tabel 6 menunjukkan parameter yang tidak memenuhi standar mutu air adalah: (1) parameter fisik yaitu kekeruhhan 35,69* pada stasiun V (berdekatan dengan kawasan pertanian di Dusun Buyan); (2) parameter kimia yaitu kadar DO adalah $5,15^{*}<6$ terjadi pada stasiun V, kadar BOD5 15,61*, 17,07*, $22,27 *, 27,51^{*}$ dan $44,82^{*}>>2$ (pada semua stasiun), kadar COD 27,74*, 29,95*, 38,41*, $47,78^{*}$ dan $71,07^{*}$ (pada semua stasiun),
$\mathrm{NO}_{2} \quad 0,77^{*}$ dan $0,88^{*}$ (pada stasiun III/pemukiman dan IV/pertanian), Ammonia $0,62^{*} \mathrm{mg} \cdot \mathrm{L}^{-1}$ (stasiun V), Phospat 0,255* mg. $\mathrm{L}^{-1}$ (stasiun $\mathrm{V}$ ); (3) parameter biologi yaitu fecal coliform 102* MPN/100mL (stasiun III/dekat pemukiman) dan total coliform 1260* MPN/100 mL (stasiun III).

Data hasil dari beberapa parameter yang tidak sesuai standar mutu air kelas I ditampilkan pada Gambar 2. s/d Gambar 10.

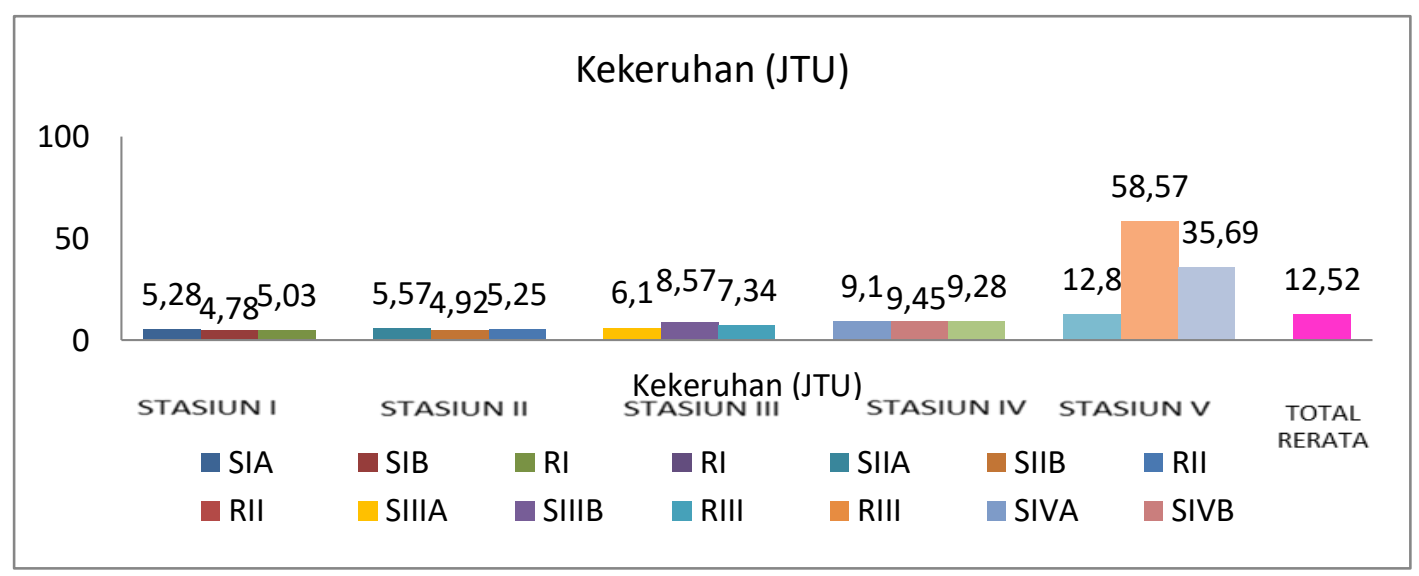

Gambar 2.

Grafik Nilai Kekeruhan di Perairan Danau Buyan

Nilai kekeruhan pada perairan Danau Buyan berkisar antara 4,78 - 58,57 JTU dengan rerata 12,52 JTU. Nilai kekeruhan yang tinggi yang tidak memenuhi persyaratan baku mutu terjadi pada stasiun $\mathrm{V}$ yakni dekat lahan pertanian.

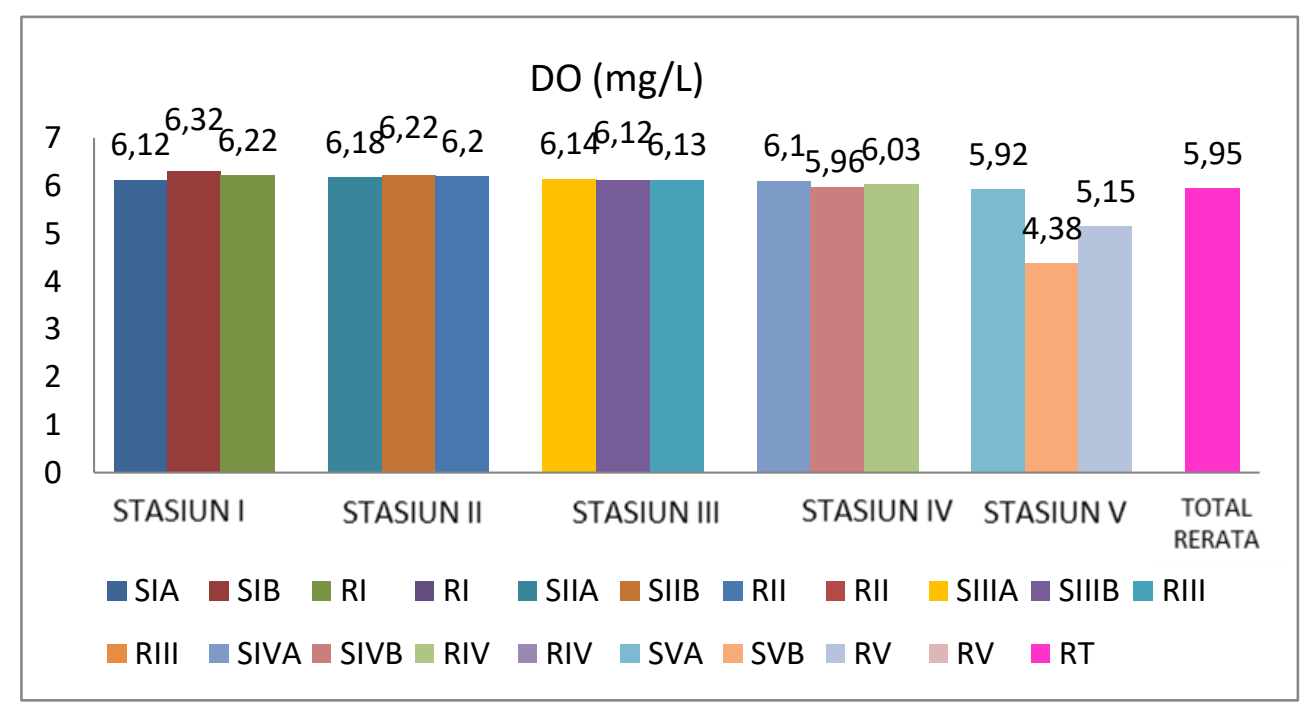

Gambar 3.

Grafik Nilai DO di Perairan Danau Buyan

Nilai kandungan DO air Danau Buyan yaitu antara $4,38-6,32 \mathrm{mg} . \mathrm{L}^{-1}$ yang reratanya adalah 5,95 mg. $\mathrm{L}^{-1}$. Nilai DO yang tidak sesuai dengan standar/lebih rendah 
terjadi pada stasiun V/dekat pertanian. Hal ini menunjukkan bahwa di stasiun $\mathrm{V}$ yakni dekat lahan pertanian terajadi pencemaran dengan bahan organik sehingga oksigen terlarut menjadi rendah karena digunakan untuk mengoksidasi bahan organik terlarut.

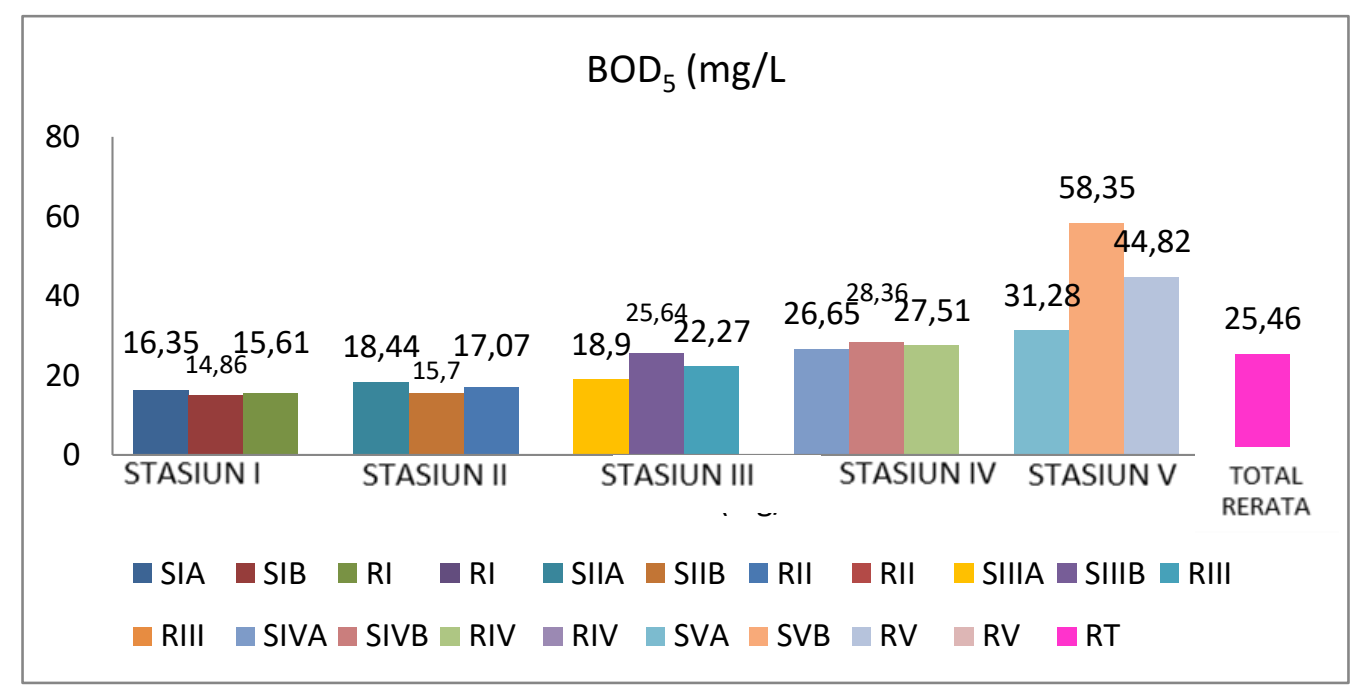

Gambar 4.

Grafik Nilai $\mathrm{BOD}_{5}$ di Perairan Danau Buyan

Kandungan $\mathrm{BOD}_{5}$ di perairan Danau Buyan berkisar antara 14,86 - 58,35 mg.. $\mathrm{L}^{-1}$ dengan rerata $25,46 \mathrm{mg} . \mathrm{L}^{-1}$. Nilai $\mathrm{BOD}_{5}$ ini semuanya melampaui standar yang ditetapkan dan nilainya yang lebih tinggi terjadi pada stasiun dekat pemukiman dan pertanian. Hal ini juga menunjukkan bahwa aktivitas masyarakat dipermukiman dan pertanian menghasilkan limbah organik yang lebih banyak dan mencemari perairan disekitar danau sehingga diperlukan oksigen yang lebih banyak untuk mengoksidasi limbah organik yang lebih banyak.

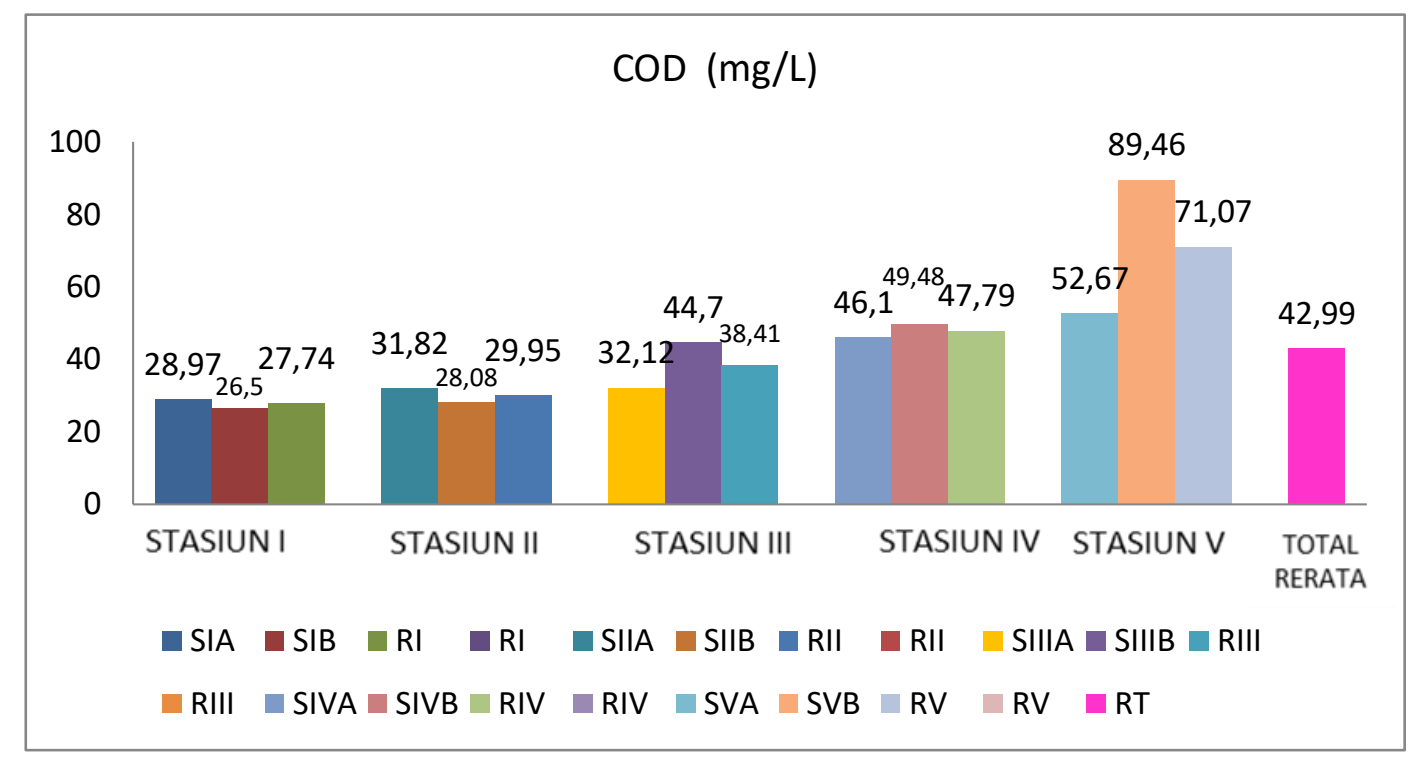

Gambar 5.

Grafik Nilai COD di Perairan Danau Buyan

Demikian juga nilai kandungan COD di perairan Danau Buyan juga melampaoi nilai standar yaitu berkisar antara 26,5 - 89,46 mg. $\mathrm{L}^{-1}>10 \mathrm{mg} . \mathrm{L}^{-1}$ yang nilai reratanya 42,96 
mg. $\mathrm{L}^{-1}$. Kadar COD yang melebihi standar, juga terjadi pada stasiun yang dekat dengan kawasan pertanian dan kawasan permukiman. Ini menunjukkan bahwa air Danau Buyan mengalami pencemaran dengan limbah organik yang bersumber dari aktivitas permukiman dan pertanian sehingga diperlukan oksigen yang lebih banyak untuk mengoksidasi secara kimia seluruh limbah organik yang bersumber dari aktivitas permukiman dan pertanian.

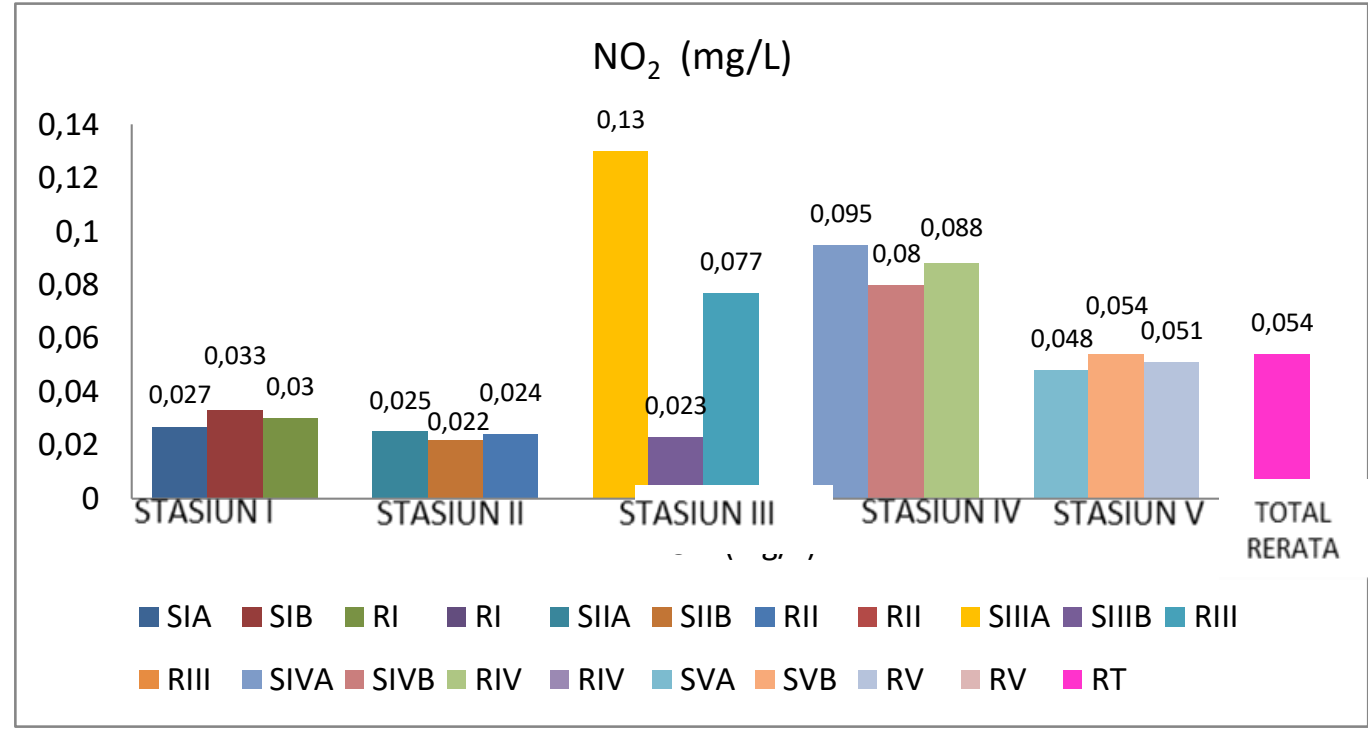

Gambar 6.

Grafik Nilai $\mathrm{NO}_{2}$ di Periran Danau Buyan

Nilai kandungan $\mathrm{NO}_{2}$ dalam air Danau ini berarti bahwa aktivitas didaerah Buyan antara 0,022 - 0,13 mg. $\mathrm{L}^{-1}$ yang permukiman dan pertanian juga reratanya adalah $0,054 \mathrm{mg} . \mathrm{L}^{-1}$. Nilai menghasilkan limbah anorganik yang berasal kandungan $\mathrm{NO}_{2}$ yang melehihi standar dari pemakaian pupuk Nitrogen di kawasan terdapat pada stasiun III dan IV (dekat tersebut.

daerah aktivitas permukiman dan pertanian)

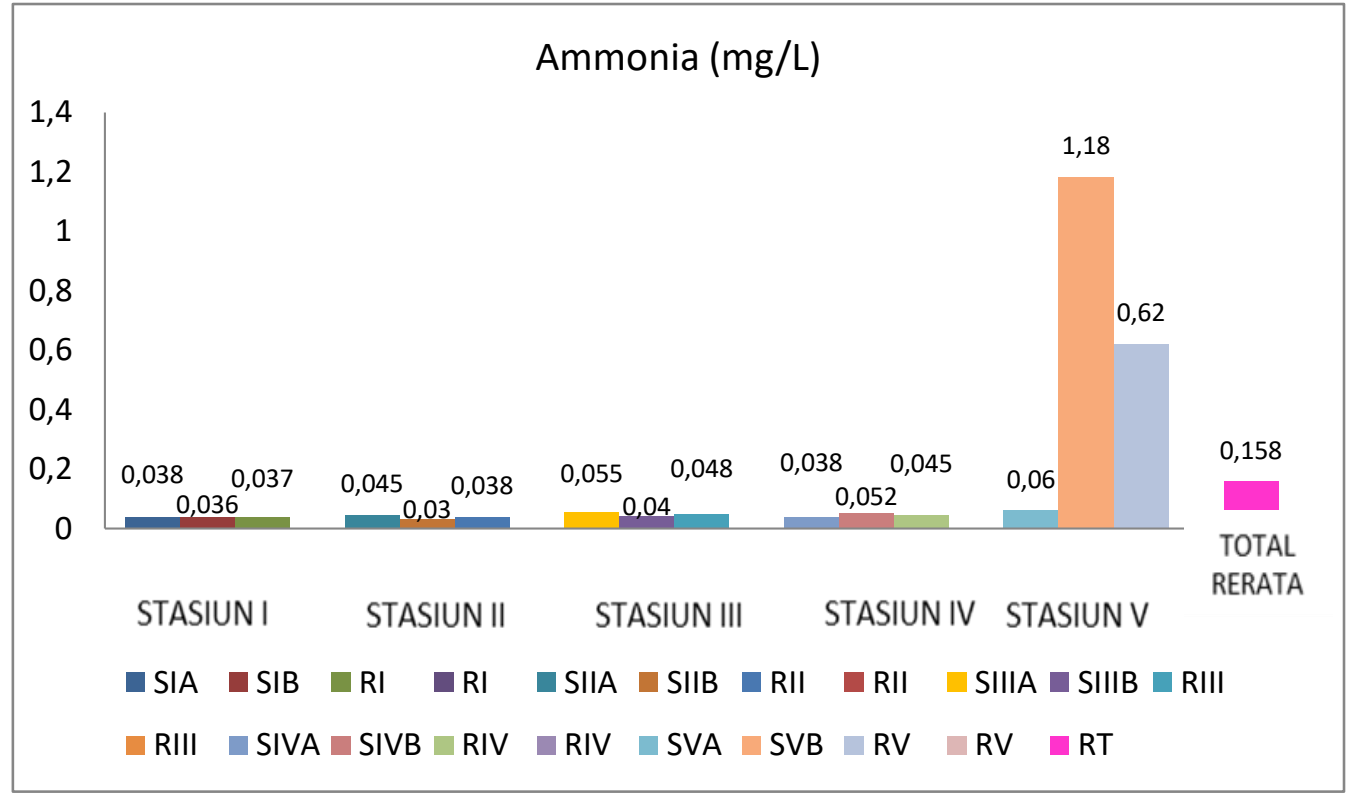

Gambar 7.

Grafik Nilai Ammonia di Perairan Danau Buyan 
Kandungan ammonia dalam air Danau Buyan antara $0,03-1,18 \mathrm{mg} . \mathrm{L}^{-1}$, yang reratanya $0,158 \mathrm{mg} . \mathrm{L}^{-1}$ melebihi standar standar yang ditetapkan. Nilai kandungan ammonia yang tinggi terjadi pada stasiun $\mathrm{V}$ (dekat aktivitas daerah pertanian). Hal ini juga membuktikan bahwa aktivitas pertanian di dekat danau menumbang limbah yang mengandung nitrogen cukup tinggi yang kemungkinan terbesarnya berasal dari pemakain pupuk Nitrogen.

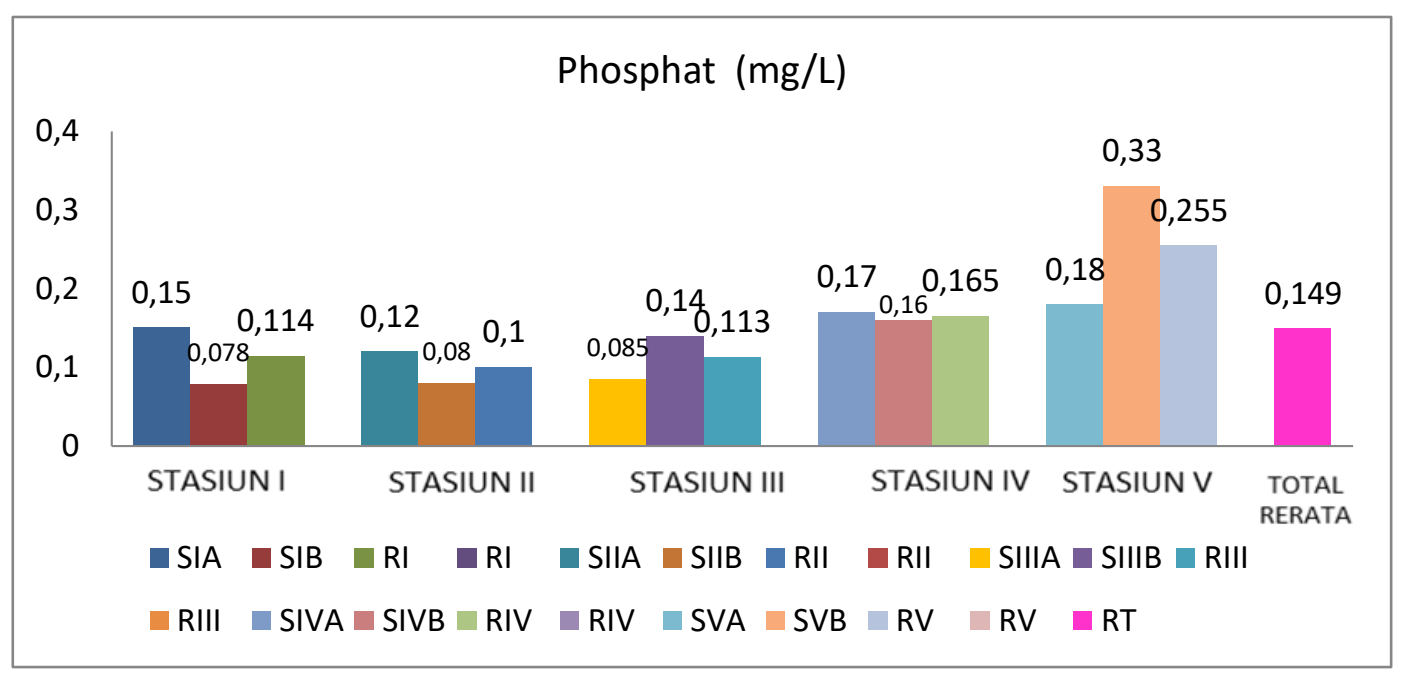

Gambar 8.

Grafik Nilai Phosphat di Perairan Danau Buyan

Kandungan phosphat air Danau Buyan adalah $0,078-0,33 \mathrm{mg} \cdot \mathrm{L}^{-1}$ reratanya 0,149 $\mathrm{mg} . \mathrm{L}^{-1}$. Nilai phosphat yang tinggi melampaui standar yang ditetapkan juga teradi pada substasiun V (daerah pertanian).
Hal ini juga membuktikan bahwa aktivitas di daerah pertanian menumbang limbah yang mengandung phosfat terhadap perairan danau yang berasal dari pemakaian pupuk phosfat.

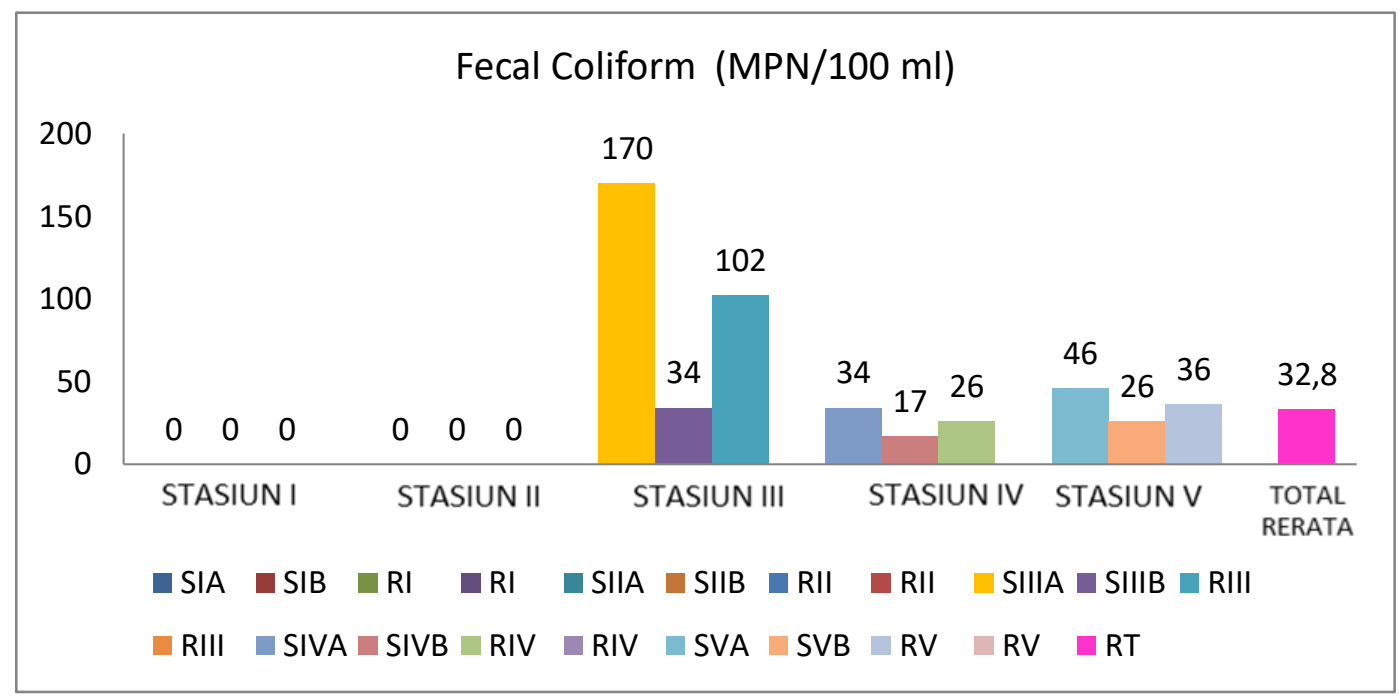

Gambar 9.

Grafik Nilai Fecal Coliform di Perairan Danau Buyan 
Hasil analisis MPN Fecal Coliform di perairan Danau Buyan berisar dari 0 sampai dengan $102 \mathrm{MPN} / 100 \mathrm{~mL}$ dan yang tertinggi dan melampaoi standar yang ditetapan adalah pada stasiun III (dekat permukiman). Ini menunjukkan bahwa perairan Danau Buyan dekat permukinan tercemar dengan tinja coliform.

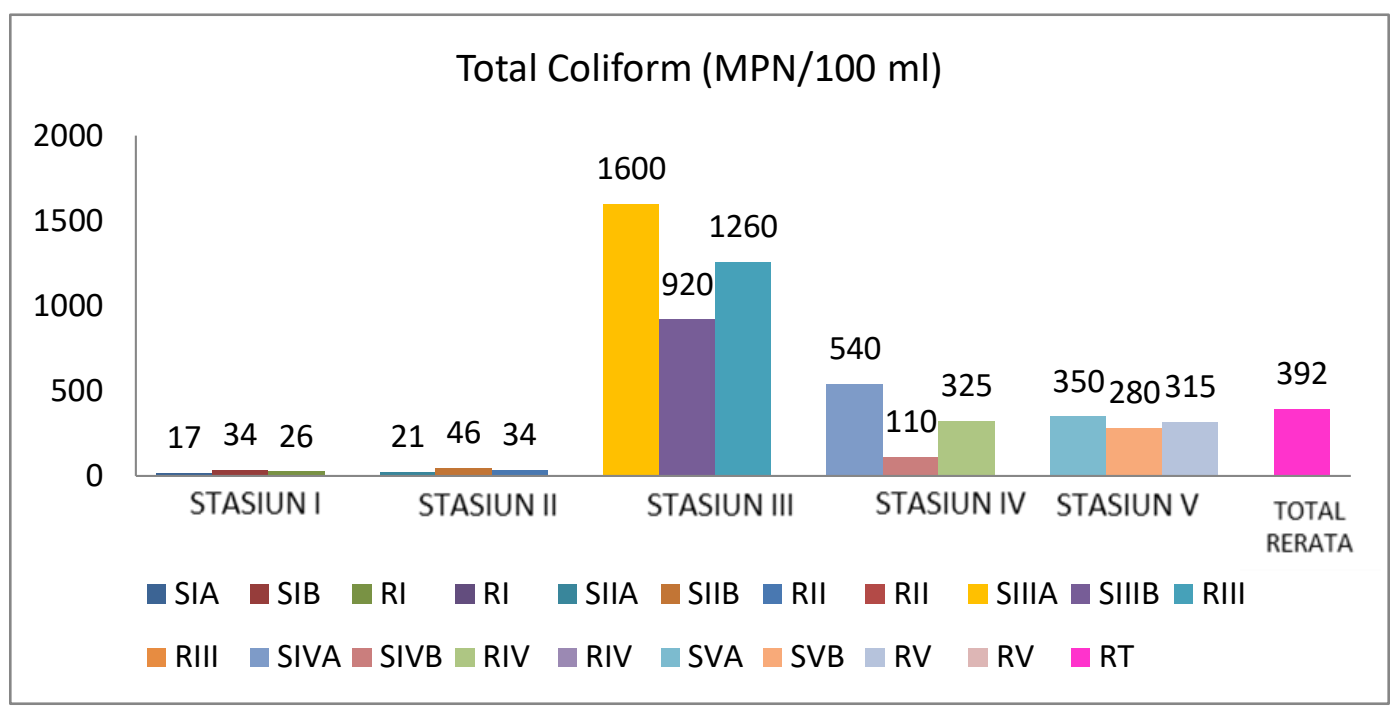

Gambar 10.

Grafik Nilai Coliform di Perairan Danau Buyan

Nilai total coliform dalam air Danau Buyan yaitu antara $17-1600$ MPN/100 mL dengan rerata 392 (MPN/100 ml). Nilai Total Coliform tertinggi dan melebihi standar yang ditetapan ditemukan pada stasiun III (daerah pemukiman). Senada dengan fecal coliform perairan danau dekat daerah permukiman tercemar dengan coliform yang berasal dari ativitas permukiman.

\subsubsection{Tingkat pencemaran air Danau Buyan}

Penentuan kriteria tingkat pencermaran air pada penelitian ini menggunakan Metode STORET yang hasilnya disajikan dalam Tabel 7.

Tabel 7. Data Hasil Analisis Metode Storet dan Status Tingat Pencemaran Perairan Danau Buyan

\begin{tabular}{|c|c|c|c|c|c|}
\hline Lokasi & $\begin{array}{c}\text { Parameter yang melebihi } \\
\text { Standar }\end{array}$ & $\begin{array}{l}\text { Indeks } \\
\text { Storet }\end{array}$ & Kelas & Kondisi & $\begin{array}{l}\text { Kategori } \\
\text { Tercemar }\end{array}$ \\
\hline Sta I. & $\mathrm{BOD}_{5}$ dan COD & -20 & $\mathrm{C}$ & Sedang & Sedang \\
\hline Sta II. & $\mathrm{BOD}_{5}$ dan COD & -20 & $\mathrm{C}$ & Sedang & Sedang \\
\hline Sta III. & & -54 & $\mathrm{D}$ & Buruk & Berat \\
\hline Sta IV. & $\mathrm{DO}, \mathrm{BOD}_{5}, \mathrm{COD}, \mathrm{NO}_{2}$ & -34 & $\mathrm{D}$ & Buruk & Berat \\
\hline Sta V. & $\begin{array}{l}\text { Kekeruhan, DO, } \mathrm{BOD}_{5}, \mathrm{COD} \text {, } \\
\text { Ammonia dan Phosphat }\end{array}$ & -48 & $\mathrm{D}$ & Buruk & Berat \\
\hline $\begin{array}{l}\text { Air Danau } \\
\text { Buyan }\end{array}$ & $\begin{array}{l}\text { Kekeruhan, DO, } \mathrm{BOD}_{5}, \mathrm{COD}, \\
\mathrm{NO}_{2} \text {, Ammonia, Phosphat, Fecal } \\
\text { Coliform, dan Total Coliform }\end{array}$ & -40 & $\mathrm{D}$ & Buruk & Berat \\
\hline
\end{tabular}

Tabel 7 menunjukkan bahwa kondisi perairan Danau Buyan di masing-masing stasiun serta secara keseluruhan tingkat pencemarannya mulai dari tingkat sedang 
sampai tingkat berat, dengan indeks storet berkisar -20 s/d -54. Pada stasiun I dan II (dekat daerah Hutan dan ditengah danau) tergolong status mutu air klas $\mathrm{C}$ dengan kriteria tingkat pencemaran sedang. Selanjutnya pada stasiun III, IV, dan V (dekat daerah permukiman dan pertanian) tergolong status mutu air kelas D dengan kriteria tingkat pencemaran berat. Secara keseluruhan tingkat pencemarannya adalah tingkat berat dengan indeks strolet -40 (Tabel 7).

\subsection{Pembahasan}

\subsubsection{Sumber Pencemaran perairan Danau Buyan.}

Dari hasil penelitian menunjukkan bahwa sumber pencemar perairan Danau Buyan adalah aktivitas masyarakat di kawasan permukiman dan aktivitas dikawasan pertanian disekitar danau. Aktivitas masyarakat dikawasan permukiman seperti aktivitas rumah tangga sehari-hari berupa kegiatan makan-minum, pembersihan lantai, mencuci, mandi, penggunaan toilet (tinja dan air seni) serta kegiatan jenis lainnya menghasilkan limbah cair domestik yang dibuang ke sistem pembuangan limbah cair domestik pada akhirnya akan mengalir ke danau. Hasil penelitian Marganof (2007) juga menunjukkan bahwa aktivitas-aktivitas masyarakat seperti pertanian dan peternakan, permukiman dan perhotelan di sempadan danau, sebagai sumber bahan pencemar air danau (Marganof, 2007). Aktivitas di permukiman merupakan penyumbang utama bahan organik yang masuk ke perairan danau sebagai pencemar. Di samping itu ada juga masyarakat memanfaatkan pekarangannya sebagai lahan pertanian sehingga menyebabkan perairan danau dekat permukiman menjadi tercemar. Hal ini ditunjukkan oleh hasil penelitian bahwa stasiun III (dekat permukiman) nilai $\mathrm{BOD}_{5}$, COD, $\mathrm{NO}_{2}$, Fecal Coliform, dan Total Coliform melebihi ambang batas standar yang ditetapkan sehingga kualitas airnya dalam kategori buruk dengan tingkat pencemaran yang berat.

Sumber pencemar dari aktivitas masyarakat di kawasan pertanian di sekitar danau yang berupa pemupukan dengan pupu anorganik seperti NPK dan lain-lain maupun pupuk organik dan penyemprotan hama dengan pestisida serta kegiatan yang menghasilkan sisa-sisa bahan organik hasil pertanian akan menghasilkan limbah bahan organik dan residu pupuk anorganik dan pestisida yang pada akhirnya akan mengalir ke perairan danau.

Endarini (2004), juga melaporkan bahwa kegiatan masyarakat yang berpotensi memberi dampak pemasukan total $\mathrm{P}$ dan total $\mathrm{N}$ pada perairan adalah aktivitas pertanian. Total $\mathrm{N}$ dan total P Danau Buyan adalah sebesar 22,46 ton/tahun dan 2,44 ton/tahun (Endarini, 2004). Nilai total yang tinggi ini merupakan dampak dari kegiatan pertanian di kawasan sekitar danau.

Tercemarnya perairan danau akibat dari aktivitas pertanian baik yang langsung maupun tak langsung dikarenakan oleh residu dari penggunaan pestisida dan pupuk yang berlebihan mengalir kedalam perairan danau. Residu pestisida yang mengalir kedalam danau sebagian besar diserap oleh partikel-partikel suspensi yang diam secara terpisah dari bahan organik. Residu pestisida memiliki kesetabilan yang tinggi sehingga tidak terlarutkan oleh air tapi oleh pelarut nonpolar seperti lemak dan lain-lain dan pada akhirnya melekat pada partikel-partikel halus dan terakumulasi dalam air danau sehingga mencemari air danau dan merusak ekosistim yang ada (Cornel \& Miller, 1995 dalam (Marganof, 2007).

\subsubsection{Kualitas air Danau Buyan}

Hasil penelitian menunjukkan bahwa peraiaran Danau Buyan pada stasiun IV dan $\mathrm{V}$ yaitu dekat dengan kawasan pertanian tercemar yang dicerminkan oleh nilai Kekeruhan, DO, $\mathrm{BOD}_{5}, \mathrm{COD}, \mathrm{NO}_{2}$, Ammonia dan Phosphat tidak sesuai dengan standar yang ditetapkan sehingga menyebabkkan kualitas airnya berada dalam 
kategori buruk dengan tingkat pencemaran pada kategori berat.

Kualitas air Danau Buyan yang diukur berdasarkan kandungan parameter fisika, kimia dan biologi, dimana nilai kandungan parameter hasil pengukurannya dibandingkan dengan standar kualitas air kelas I yang mengacu pada Pergub Bali Nomor 16 Tahun 2016 menunjukkan bahwa, kualitas perairan Danau Buyan kondisinya buruk dengan katagori tingkat pencemarannya berat pada indeks STRORET -40. Hal ini ditunjukkkan oleh hasil penelitian dari parameter kimia DO yang tidak mencapai persyaratan minimal $6 \mathrm{mg} / \mathrm{L}$ serta BOD dan COD yang melampaui persyaratan maksimal yaitu $2 \mathrm{mg} / \mathrm{L}$ dan 10 $\mathrm{mg} / \mathrm{L}$. Hasil ini jika dibandingkan dengan hasil penelitian Badan Lingkungan Hidup (BLH) Provinsi Bali tahun 2017 dan 2018 yang menyatakan bahwa tingkat pencemarannya mengalami peningkatan dari tingkat ringan ke sedang diakibatkan oleh dua parameter kimia yaitu COD dan BOD. Hasil penelitian ini juga menunjukkan tingkat pencemaran yang meningkat dari hasil penelitian BLH Provinsi Bali tahun 2018 yaitu dari tingkat sedang ke tingkat berat. Peningkatan ini juga diakibatkan selain oleh parameter kimia DO, BOD dan COD juga disebabkan oleh kandungan bakteri Fecal Coliform tinja dan Total Coliform. Kecenderungan peningkatan tingkat pencemaran air Danau Buyan ini disebabkan oleh peningkatan aktivitas penduduk disekitar danau yang menghasilkan limbah cair dari aktivitas permukiman (domestik) dan limbah dari aktivitas pertanian berupa pupuk dan pemakaian pestisida yang berpotensi mencemari perairan danau dengan konsentrasi bahan organik yang cukup tinggi.

Rendahnya kadar DO salah satu sebabnya adalah tingginya kadar BOD. Limbah cair yang bersumber dari aktivitas masyarakat di permukiman yang mencemari perairan biasanya mengandung bahan organik, bakteri dan padatan tersuspensi. Limbah seperti ini mengakibatkan $\mathrm{BOD}_{5}$ perairan menjadi tinggi. Bahan organik dan anorganik yang mengendap di dasar perairan akan memerlukan banyak oksigen untuk proses oksidasi secara biologi maupun kimia. Hal ini menyebabkan oksigen berkuranf dan menyebabkan DO menjadi rendah (Sugianti \& Astuti, 2018). DO (dissolved oxygen) adalah kandungan oksigen terlarut dalam perairan yang dhasikan dari difusi oksigen atmosfir dan oksigen hasil fotosintesis tanaman air termasuk fitoplangton. Dengan demikian penguraian/oksidasi bahan organik dan anorganik dalam perairan akan mengurangi DO (Anggraini, Simarmata, \& Sihotang, 2015).

BOD merupakan kebutuhan oksigen biologi yaitu banyaknya oksigen dalam perairan yang diperlukan mikroorganisma untuk menguraikan bahan organik dalam perairan tersebut. Oleh karena itu BOD dapat menggambarkan kandungan bahan organik dalam perairan tersebut (Effendi, 2003). Kalau $\mathrm{BOD}_{5}$ adalah jumlah oksigen yang digunakan mikroorganisma untuk menguraikan bahan organik di perairan selama jangka waktu 5 hari (Salmin, 2005). Menurut Anggoro (1996) Banyaknya bahan organik dalam limbah yang mencemari perairan akan menyebabkan proses penguraiannya oleh mikroorganisme juga banyak sehingga kandungan $\mathrm{BOD}_{5}$ menjadi tinggi (Riki Saputra, Restu, \& Ayu Pratiwi, 2017).

Jika banyak bahan organik dalam limbah yang mencemari perairan tidak terurai secara cepat sehingga berdasarkan pengujian $\mathrm{BOD}_{5}$ perhari kurang akurat maka diperlukan pengujian COD untuk menentukan jumlah bahan organik dari limbah yang mencemari perairan (Sastrawijaya, 1991). COD perairan adalah jumlah oksigen yang digunakan dalam penguraian bahan organik secara kimia menjadi karbon dioksida dan air baik yang dapat diuraikan secara biologi maupun yang tidak. Karena oksidasi secara kimia dapat mengoksidasi semua bahan organik maka untuk menggambarkan bahan organik dalam perairan tersebut paling baik ditentukan dengan COD (Effendi, 2003). 
Hasil penelitian menunjukkan bahwa rerata konsentrasi DO yang rendah, dan rerata konsentrasi $\mathrm{BOD}_{5}$ maupun rerata konsentrasi COD yang tinggi, pada stasiun IV dan V (dekat kawasan pertanian) serta tingginya nilai bakteri Fecal Coliform maupun Total Coliform pada stasiun III (dekat kawasan permukiman). Kondisi ini diakibatkan limbah cair dari aktivitas masyarakat disekitar kawasan memiliki kandungan bahan organik yang tinggi. Sehingga menyebabkan kualitas perairan Danau Buyan dalam kondisi buruk dan kategori status mutu air kelas D atau tingkat pencemarannya berat. Dengan demikian perairan danau buyan tidak sesuai lagi peruntukkannya untuk air baku air minum, dan hanya sesuai untuk mengairi pertanian.

\section{SIMPULAN}

Sumber pencemaran air Danau Buyan adalah aktivitas masyarakat di kawasan permukiman dan kawasan pertanian. Kualitas air Danau Buyan secara umum berada dalam kondisi buruk. Tingkat pencemarannya berada pada kategori berat dengan indeks STORET -40 .

\section{DAFTAR PUSTAKA}

Anggraini, N., Simarmata, A. H., \& Sihotang, C. (2015). Dissolved Oxygen Concentration From the Water around the Floating Cage Fish Culture Area and from the Area with No Cage, in the DAM site of the Koto Panjang Reservoir. Jurnal Limnotek, XIV(2), 109-118.

https://doi.org/10.11164/jjsps.16.4_704 $-3$

APHA. (1998). Standard Methods for the Examination of water and Wastewater. American Physical Education Review, 24(9), 481-486.

Badan Standardisasi Nasional. (1995). SNI 19-3983-1995: Spesifikasi timbulan sampah untuk kota kecil dan kota sedang di Indonesia (Specification solid waste generation rates for large and small cities). SNI 19-3983-1995.

Effendi, H. (2003). Telaah kualitas air bagi pengelolaan sumber daya dan lingkungan perairan. Yogyakarta: Kanisius.

Endarini, T. (2004). Dampak Kegiatan Masyarakat Pada Kualitas Air Danau Buyan, Kabupaten Buleleng, Bali. Universitas Indonesia.

Marganof. (2007). Model Pengendalian Pencemaran Perairan Di Danau Maninjau Sumatera Barat. IPB (Bogor Agricultural University).

Nopiantari, N. P. V., Arthana, I. W., \& Astarini, I. A. (2017). Dampak Kegiatan Pertanian Terhadap Tngkat Eutrofikasi dan Jenis-Jenis Fitoplankton di Danau Buyan Kabupaten Buleleng Provinsi Bali. Ecotrophic: Jurnal Ilmu Lingkungan (Journal of Environmental Science), 11(1).

https://doi.org/https://doi.org/10.24843/ EJES.2017.v11.i01.p08

Nugroho, A. S., Tanjung, S. D., \& Hendrarto, B. (2014). Distribusi Serta Kandungan Nitrat Dan Fosfat Di Perairan Danau Rawa Pening. Bioma, 3(1), 27-41. https://doi.org/https://doi.org/10.26877/ bioma.v3i1,\%20April.648

Provinsi Bali, P. (2016). Lampiran II Peraturan Gubernur Bali Nomor: 16 Tahun 2016 Tanggal: 14 Maret 2016, 35-37.

Purnama, S. G. (2016). Eurotrofikasi dan Dampak Bagi Lingkungan Sekitar: Kasus di Danau Buyan. Denpasar.

Putra Manuaba, I. B. (2007). Cemaran Pestisida Klor-Organik dalam Air Danau Buyan Buleleng Bali. Jurnal Kimia (Journal of Chemistry), 1(2). 
Riki Saputra, I. W. R., Restu, I. W., \& Ayu Pratiwi, M. (2017). Analisis Kualitas Air Danau Sebagai Dasar Perbaikan Manajemen Budidaya Perikanan di Danau Buyan Kabupaten Buleleng, Provinsi Bali. ECOTROPHIC: Jurnal Ilmu Lingkungan (Journal of Environmental Science), 11(1), 1. https://doi.org/https://doi.org/10.24843/ EJES.2017.v11.i01.p01

Salmin. (2005). Oksigen Terlarut (DO) Dan Kebutuhan Oksigen Biologi (BOD) Sebagai Salah Satu Indikator Untuk Menentukan Kualitas Perairan. Oseana, 30(3), 21-26.

Sastrawijaya, A. T. (1991). Pencemaran Lingkungan. Jakarta: Rineka Cipta.
Sudji, N. W. (2015). Kebijakan Pembangunan Kawasan Tri-Danau (Beratan, Buyan, Tamblingan) Provinsi Bali. In Prosiding Simposium Analisis Daya Dukung dan Daya Tampung Sumber Daya Air di kawasan TriDanau Beratan, Budyan, dan Tamblingan Provinsi Bali. Denpasar: UPT Balai Konservasi Tumbuhan Kebun Raya Eka Karya Bali-LIPI.

Sugianti, Y., \& Astuti, L. P. (2018). Respon Oksigen Terlarut Terhadap Pencemaran dan Pengaruhnya Terhadap Keberadaan Sumber Daya Ikan di Sungai Citarum. Jurnal Teknologi Lingkungan, 19(2), 203.

https://doi.org/10.29122/jtl.v19i2.2488 